\title{
Критерії відбору та первинна обробка емпіричного матеріалу паралельного корпусу юридичних текстів
}

\author{
Selection Criteria and Initial Processing of Empirical Material \\ for a Parallel Corpus of Legal Texts
}

\section{Svitlana MATVIEIEVA / Світлана MATB€ЄBA ${ }^{1}$}

National Pedagogical Dragomanov University (Ukraine)

Національний педагогічний університет імені М.П. Драгоманова (Україна)

\begin{abstract}
The article deals with the formation of criteria for the primary selection of legal texts for the English-Ukrainian parallel corpus of legal texts. The author has developed a classification of legal texts on the basis of the style and text genres, taking into account the types of legal acts, and makes an attempt to combine legal and linguistic characteristics applicable to the classification of legal documents. The article proposes the structure of the metadata card for corpus texts (original and translation), which are tested on text samples. The need for metatext data and extra-linguistic information for working with corpus texts is substantiated in the article.
\end{abstract}

Keywords: genre classification, parallel corpus, metadata, document card, legal text

Анотація

Статтю присвячено питанню формування критеріїв первинного відбору правничих текстів для англо-українського паралельного корпусу юридичних текстів. Автором розроблено класифікацію юридичних текстів за ознаками сфери обслуговування й жанрів текстів із урахуванням типів нормативних актів, що становить спробу поєднання юридичних та лінгвістичних характеристик, які застосовуються до класифікації юридичних документів. У статті запропоновано структуру картки метаданих корпусних текстів

1 (D) https://orcid.org/0000-0002-8357-9366. 
(оригіналу та перекладу), котру апробовано на текстових зразках; обгрунтовано необхідність метатекстових даних та екстралінгвістичної інформації для роботи 3 корпусними текстами.

Ключові слова: жанрова класифікація, паралельний корпус текстів, метадані, картка документу, юридичний текст

\section{Streszczenie}

Artykuł poświęcony jest sformułowaniu kryteriów pierwotnego wyboru tekstów prawnych dla angielsko-ukraińskiego korpusu równoległego tekstów prawnych. Autor opracował klasyfikację tekstów prawnych na podstawie stylu i gatunku tekstu, z uwzględnieniem rodzajów aktów normatywnych oraz podejmuje próbę połączenia charakterystyk prawnych i językowych, mających zastosowanie przy klasyfikacji dokumentów prawnych. W artykule zaproponowano strukturę karty metadanych dla tekstów korpusowych (oryginału i tłumaczenia), która została przetestowana na próbkach tekstowych. W artykule uzasadniono także potrzebę uwzględnienia danych metatekstowych i informacji pozajęzykowych przy pracy z tekstami korpusowymi.

Słowa kluczowe: typologia gatunkowa, korpus równoległy, metadane, karta dokumentu, tekst prawny

\section{1. Вступ}

Активне застосування корпусного підходу в лінгвістичній науці та використання здобутків корпусної лінгвістики в мовній теорії та практиці вимагає вирішення низки питань, які до сьогодні не отримали достатньої уваги дослідників. Серед таких питань і проблема укладання й використання паралельних корпусів текстів із українською мовою як мовою перекладу.

На сьогодні у мовознавстві проблемам паралельних іноземноукраїнських корпусів присвячено невелику кількість робіт, у яких розглянуто окремі питання укладання, структури та використання паралельних корпусів. У цій царині працюють українські та зарубіжні дослідники, які розробляють та вивчають паралельні корпуси 3 українською мовою, а саме: англійська/українська - Т. Анохіна (2018), Т. Бобкова (2008), Ю. Дем'янчук (2017), Н. Леміш (2018, 2019), болгарська/українська - О. Сірук, I. Держанський (2013), польська/ українська - Н. Коциба (2016), російська/українська - О. ТищенкоМонастирська, М. Шведова, Д. Січінава (2011), декілька мов/українська Н. Дарчук (2017), К. Лебєдєв (2012) та інші. 
Метою розвідки $\epsilon$ розробка критеріїв відбору та принципів первинної обробки текстів для англо-українського паралельного юридичного корпусу.

Заявлена мета вимагає вирішення таких завдань:

- встановити основні критерії відбору юридичних текстів англійською мовою та їхніх перекладів українською;

- розглянути основні принципи первинної обробки корпусних текстів;

- розробити картку метаданих юридичних текстів, що включаються до корпусу.

Об’єктом нашого дослідження $€$ пілотний англо-український паралельний корпус юридичних текстів, укладений 3 правничих документів англійською мовою та їхніх перекладів українською. Предмет роботи - екстралінгвістичні показники текстів англо-українського юридичного паралельного корпусу.

\section{2. Критерії відбору юридичних текстів}

При укладанні будь-якої бази даних виникає необхідність унормування принципів i підходів до відбору одиниць для такої бази. $\mathrm{He}$ $\epsilon$ виключенням і корпус текстів, до складу якого мають увійти тільки ті тексти, які відповідають певним встановленим критеріям. Ці критерії $є$ не випадковим набором вимог, а доказово обгрунтованим переліком ознак для відбору текстів, у нашому випадку - юридичних. Отже, перед укладачем корпусу юридичних текстів стоїть завдання розробки реєстру основних вимог до спеціального тексту як результату когнітивномовленнєвої діяльності правника.

На етапі попередньої селекції текстів обов'язковими вважаємо врахування наступних текстових та позатекстових характеристик:

\section{1. Мовна автентичність тексту}

Для включення певного тексту до паралельного англо-українського корпусу, відповідно до цього критерію, оригінальна мова тексту $\epsilon$ англійська, а мова паралельного тексту (мова безпосереднього прямого перекладу) - українська. Введення до корпусу виключно автентичних текстів забезпечить високий індекс показника якості текстового масиву. 


\section{2. Жанрова приналежність}

Цей критерій забезпечує відбір текстів із наступними ознаками: чітко визначена сфера застосування (офіційно-ділове спілкування), фіксована структура тексту, стабільне понятійно-термінологічне наповнення, відсутність суб'єктивної складової мовної особистості автора тощо.

\section{3. Час створення тексту}

Визначення цілей будь-якого корпусу вимагає обмеження часових меж створення текстів, які включаються до такого корпусу. Так, паралельний корпус юридичних текстів, створений із метою практичної допомоги перекладачам, вимагає залучення текстів сучасності (умовно, кінець XX - початок XXI століть) без урахування динаміки й діахронічних характеристик метамови юриспруденції.

Всі ці критерії $\epsilon$ не тільки показниками для відбору корпусних текстів, але й формують частину екстралінгвістичних метаданих кожного тексту, що включено до корпусу, про які йтиметься далі.

Критерієм, який потребує особливої уваги і який на сьогодні не отримав однозначного вирішення в лінгвістичній науці, $є$ критерій жанрової приналежності текстів.

\section{3. Класифікація юридичних текстів і документів}

\section{1. Класифікація галузей законодавства України}

Будь-яка класифікація професійних текстів і термінів має спиратися на внутрішньогалузеву класифікацію спеціальних текстів і документів, які забезпечують фахову комунікативно-інформаційну складову кожної наукової та технічної сфери.

Одним із основних завдань розробки всебічної класифікації юридичних текстів $€$ врахування не тільки мовних та дискурсивних характеристик текстів, що класифікуються, а й особлива увага до галузевих характеристик таких текстів, тобто органічне і нерозривне поєднання лінгвістики та юриспруденції. Такий підхід забезпечує необхідне підгрунтя та інструментарій для застосування комплексу характеристик та маркерів при аналізі й кваліфікації мовного матеріалу.

У 2004 році було розроблено та введено до офіційного професійного та наукового обігу "Класифікатор галузей законодавства України" (Класифікатор галузей законодавства України 2004) (наказ Міністерства юстиції України від 02.06.2004 р. № 43/5) як “єдине джерело класифікації 
українського законодавства" (Рукосуєва, 2004). Цей класифікатор мав “забезпечити предметне розміщення масиву законодавства, в тому числі відомчих нормативно-правових актів, полегшити процес створення систематизованого зібрання актів законодавства" (Рукосуєва, 2004).

Відповідно до цього класифікатору, всі галузі законодавства України поділено на 38 категорій. При цьому викликає сумнів об’єктивність такого поділу через застосування декількох кваліфікаційних маркерів в межах однієї класифікації. Умовно ці маркери можемо визначити наступним чином: галузь права (відповідно до цього маркеру виділено такі категорії: кримінальне, сімейне, цивільне законодавство тощо), при цьому дещо порушено логіку при виділенні категорії “Основи конституційного ладу" замість конституційного права (що є й певним звуженням щодо суб’єкту конституційного права); тип правовідносин, що регулюють певну сферу життєдіяльності суспільства, або юридичні інститути (відповідно до цього маркеру виділено наступні категорії: оборона, освіта, промисловість, транспорт, сільське господарство тощо); особливі суб'єкти правничої діяльності (наприклад: адвокатура, прокуратура) (при цьому категорії “Охорона громадського порядку і громадської безпеки”, “Національна безпека”, "Юстиція”, “Оборона” потребують додаткової деталізації)2.

Така класифікація при використанні для систематизації та опису корпусних текстів спричиняє складності визначення видів текстів через закладені в самій класифікації можливості перетину різних рубрик навколо того самого документу. Наприклад, будь-який нормативноправовий акт, що регулює відносини стосовно земельних ресурсів, може й має належати як до системи актів земельного права, так і може стосуватися блоків цивільного, конституційного, адміністративного права, сільського господарства, природних ресурсів, охорони довкілля, геодезії тощо.

Отже, зрозуміло, що жоден юридичний документ не може отримати однозначної характеристики за умов одночасного застосування декількох різних класифікаційних критеріїв. Ці критерії мають будувати окремі класифікатори $з$ урахуванням родо-видових та інших внутрішньосистемних взаємин.

Також незрозумілим $є$ підхід авторів класифікатору до критеріїв виділення чи не виділення певної рубрики. Так, у коментарях до класифікатору зазначено, що “одним з критеріїв виділення тієї чи іншої рубрики (підрубрики) визнається наявність визначеного, достатньо

2 Така класифікація маркерів є досить умовною; маркери виділено 3 дослідницькими лінгвістичними цілями, що в жодному разі не претендує на юридичну точність. 
розвиненого масиву нормативно-правових приписів" (Рукосуєва, 2004). Суб'єктивний підхід до оцінки критерію достатності/недостатності кількості певного матеріалу для включення його до загальної класифікації $\epsilon$ неприпустимим i вкрай непрофесійним. Більше того, такий підхід жодним чином не "відображає існуючу модель законодавства" (Рукосуєва, 2004), про яку заявляли укладачі класифікатору як про важливу характеристику такого рубрикатору, i робить майже неможливим “створення стандарту в галузі класифікації актів законодавства, яка дає можливість охватити великий обсяг нормативного матеріалу та паралельно здійснювати інформаційний пошук та систематизацію законодавства" (Рукосуєва, 2004) в таких умовах.

Все це унеможливлює органічне поєднання професійних класифікацій правових документів i лінгвістичних класифікацій юридичних текстів. Запропонована класифікація актів законодавства не може бути застосована до класифікації правових документів у нашому корпусі і вимагає розробки окремої жанрово-стильової класифікації.

\section{2. Жанрово-стильова класифікація юридичних текстів}

Одним із визнаних $\mathrm{i}$ найпоширенішим $\mathrm{y}$ лінгвістичній науці $\epsilon$ класифікація текстів за їхніми стильовими та жанровими ознаками. Так, під стилем розуміють "прагматичну ознаку мовленнєвої системи; організацію мовних засобів, принципів їхнього відбору й інтеграції в мовленні і стереотипних способів комунікативної взаємодії, зумовлену певною сферою спілкування на підставі суспільно усвідомленого вибору" (Селіванова, 2011, с. 695). Ці диференційні ознаки мовних і мовленнєвих феноменів зумовлюють розподіл мовленнєвих творів за функціональними стилями, які розглядають як “суспільно усвідомлені сукупності прийомів уживання, відбору та сполучення мовленнєвих засобів, функціонально зумовлених соціально значимою сферою спілкування" (Селіванова, 2011, с. 695). На сьогодні тексти, що обслуговують галузь права, класифікуються як такі, що належать до офіційно-ділового стилю (“функціональний різновид мовлення, який обслуговує сферу суспільно-правових відносин” (Макович, 2016, с. 94)) законодавчого та юридичного підстилів (Макович, 2016, с. 94).

Аналіз правових текстів з огляду на принципи селекції текстів для включення їх до корпусного масиву даних дає підстави об'єднати законодавчий i юридичний підстилі, але розмежувати всі тексти за ознакою типу правового акту і виділити наступні типи документів: 
нормативно-правовий (“прийнятий у встановленому порядку та відповідній юридичній формі письмовий документ уповноваженого суб'єкта правотворчості, яким встановлюються, змінюються або скасовуються юридичні норми” (Сердюк, 2010, с. 155)), індивідуальноправовий (“спосіб зовнішнього прояву формально-обов’язкового правила поведінки індивідуального характеру, яке підтверджує, встановлює, змінює або скасовує юридичні права й обов'язки персоніфікованих суб’єктів у конкретній життєвій ситуаціі” (Сердюк, 2010, с. 156)) та інтерпретаційно-правовий (“вид правового акту, що включає загальні або індивідуальні правоположення, які, хоча i не $\epsilon$ нормами права, але розгорнуто й обгрунтовано роз'яснюють їх дійсний зміст, не $\epsilon$ джерелом права, але перебувають у тісному підпорядкованому зв'язку з нормою права, яку тлумачать, і мають обов'язковий характер" (Сердюк, 2010, c. 157)). Така класифікація за рахунок деталізації специфічних характеристик дає підстави об’єднати тексти за ознаками, релевантними 3 лінгвістичної точки зору, а саме: за типом адресанту (індивідуальний, колективний, невідомий, неактуальний, узагальнений тощо) та адресату (реальний, гіпотетичний; індивідуальний, груповий, ретиальний; статусний, позиційний, ситуаційний тощо), термінологічним тезаурусом, комунікативною інтенцією (виконання, використання, дотримання, заохочення, зобов'язання, примус, покарання, обмеження тощо), структурою (специфіка будови, оформлення, систематизаціі) тощо.

Отже, для класифікації текстів, які можуть бути включені до англоукраїнського паралельного корпусу правничих текстів, нами розроблено жанрово-стильову класифікацію, засновану на ознаках сфери обслуговування, жанрів текстів і типу правового документу (акту) (див. Таблицю 1).

Наприклад, текст Конституції України класифікуємо як такий, що належить до офіційно-ділового стилю, юридичного підстилю, $\epsilon$ нормативно-правовим актом, написаним у жанрі закону.

Залучення до корпусів класифікаційних даних не тільки лінгвістики, але й юриспруденції дозволить розширити можливості професійних корпусів для галузевих правничих потреб. Використання додаткових класифікацій правових документів, розроблених з огляду на юридичну доцільність, збагатить метадані кожного тексту й зробить корпус таких текстів корисним не тільки для філологів, але й для правників. Так, класифікація нормативно-правових актів за галузями законодавства дозволить поділити всі тексти на цивільні, кримінальні, адміністративні, кримінально-процесуальні, адміністративно-процесуальні та інші, а за 
характером волевиявлення - на акти встановлення, зміни та скасування норм права.

Таблиця 1. Класифікація правничих текстів для корпусу юридичних текстів

\begin{tabular}{|c|c|c|c|c|}
\hline Стиль & Підстиль & $\begin{array}{c}\text { Вид правового } \\
\text { акту }\end{array}$ & \multicolumn{2}{|c|}{ Жанр } \\
\hline \multirow[t]{32}{*}{$\begin{array}{l}\text { офіційно- } \\
\text { діловий }\end{array}$} & $\begin{array}{l}\text { адміністративно- } \\
\text { канцелярський }\end{array}$ & & & \\
\hline & дипломатичний & & & \\
\hline & \multirow[t]{30}{*}{ юридичний } & \multirow{11}{*}{$\begin{array}{l}\text { нормативно- } \\
\text { правовий }\end{array}$} & \multicolumn{2}{|l|}{ закон } \\
\hline & & & \multirow{10}{*}{$\begin{array}{l}\text { підзаконний } \\
\text { акт }\end{array}$} & договір \\
\hline & & & & інструкція \\
\hline & & & & наказ \\
\hline & & & & положення \\
\hline & & & & постанова \\
\hline & & & & рішення \\
\hline & & & & розпорядження \\
\hline & & & & указ \\
\hline & & & & статут \\
\hline & & & & інше \\
\hline & & \multirow{12}{*}{$\begin{array}{l}\text { індивідуально- } \\
\text { правовий }\end{array}$} & \multicolumn{2}{|l|}{ вирок } \\
\hline & & & \multicolumn{2}{|l|}{ наказ } \\
\hline & & & \multicolumn{2}{|l|}{ подання } \\
\hline & & & \multicolumn{2}{|l|}{ постанова } \\
\hline & & & \multicolumn{2}{|l|}{ протест } \\
\hline & & & \multicolumn{2}{|l|}{ протокол } \\
\hline & & & \multicolumn{2}{|l|}{ рішення } \\
\hline & & & \multicolumn{2}{|c|}{ розпорядження } \\
\hline & & & \multicolumn{2}{|l|}{ угода } \\
\hline & & & \multicolumn{2}{|l|}{ указ } \\
\hline & & & \multicolumn{2}{|l|}{ ухвала } \\
\hline & & & \multicolumn{2}{|l|}{ інше } \\
\hline & & \multirow{7}{*}{$\begin{array}{l}\text { інтерпретаційно- } \\
\text { правовий }\end{array}$} & \multicolumn{2}{|l|}{ висновки } \\
\hline & & & \multicolumn{2}{|c|}{ інформаційний лист } \\
\hline & & & \multicolumn{2}{|l|}{ постанова } \\
\hline & & & \multicolumn{2}{|l|}{ рішення } \\
\hline & & & \multicolumn{2}{|l|}{ роз'яснення } \\
\hline & & & \multicolumn{2}{|l|}{ ухвала } \\
\hline & & & \multicolumn{2}{|l|}{ інше } \\
\hline
\end{tabular}


Зрозуміло, що будь-яка класифікація є певною мірою умовною, але розробка ієрархічних класифікаційних критеріїв додає об'єктивності будьякій класифікації та забезпечує вищий рівень якості роботи з текстами.

\section{4. Картка метаданих корпусного тексту}

Кожен текст, що відповідає вимогам конкретного корпусу і включається до корпусного масиву, має отримати належний опис реквізитів і зовнішніх характеристик, які часто відіграють дуже важливу роль в роботі перекладача 3 текстом. Такі реквізити мають бути організовані та систематизовані певним чином i забезпечувати користувачу зручний доступ до документу із всіма його метаданими. Під метаданими розуміють “дані про дані; в корпусі це зазвичай означає дані про тексти - наприклад, про автора, дату публікації, назву й джерело письмового тексту, або інформацію про стать, вік і соціальний клас мовця у розмовному тексті" (McEnergy, 2011, c. 246).

Структура метатекстової розмітки в межах одного корпусу має бути уніфікованою та обов'язковою для кожного корпусного тексту. Екстралінгвістична та метатекстова розмітка кожного документу вводиться в певну форму, шаблон, який називається карткою документу. Дані, які містяться в картці документу, продуктивно використовуються для відбору текстів у процесі роботи 3 корпусом. Великий обсяг позалінгвальної інформації про текст дозволяє фільтрувати масиви даних та підвищувати якість роботи (професійної, дослідницької, навчальної, перекладацької) 3 текстами.

Аналіз позамовних характеристик юридичних документів дозволяє укласти реєстр метаданих, які необхідно врахувати при створенні паралельного юридичного корпусу (див. Таблиця 2). 
Таблиця 2. Картка метаданих юридичних текстів (оригіналу й перекладу)

\begin{tabular}{|l|l|}
\hline \multicolumn{1}{|c|}{ Характеристика } & \multicolumn{1}{|c|}{ Опис } \\
\hline \multicolumn{2}{|c|}{ Текст оригіналу } \\
\hline Назва & повна + коротка (за наявності) \\
\hline Мова оригіналу & англійська \\
\hline Автор & $\begin{array}{l}\text { одна людина, організація, колективний автор, } \\
\text { невідомий автор тощо }\end{array}$ \\
\hline Стать автора ${ }^{3}$ & (нерелевантна для юридичного тексту) \\
\hline Дата створення тексту & рік / місяць / день \\
\hline Дата публікації тексту & рік / місяць / день \\
\hline Місце публікації & країна, місто \\
\hline Видавництво / орган & $\begin{array}{l}\text { назва видавництва або органу, відповідального } \\
\text { за оприлюднення документу }\end{array}$ \\
\hline \multicolumn{2}{|l|}{ Текст перекладу } \\
\hline Назва перекладу & повна + коротка (за наявності) \\
\hline Мова перекладу & українська \\
\hline Перекладач & $\begin{array}{l}\text { одна людина, організація, колективний автор, } \\
\text { невідомий перекладач тощо }\end{array}$ \\
\hline Стать перекладача & $\begin{array}{l}\text { (нерелевантна характеристика для перекладу } \\
\text { юридичного тексту) }\end{array}$ \\
\hline Дата публікації перекладу & рік / місяць / день \\
\hline Місце публікації & країна, місто \\
\hline Видавництво / орган & $\begin{array}{l}\text { назва видавництва або органу, відповідального } \\
\text { за оприлюднення перекладу }\end{array}$ \\
\hline Стиль & оріційно-діловий \\
\hline Підстиль & (обрати із запропонованих) \\
\hline Вид правового акту & (обрати із запропонованих) \\
\hline Жанр тексту & \\
\hline &
\end{tabular}

Наприклад, картка метаданих судового рішення, текст якого знаходиться у вільному доступі на сайті “European Court of Human Rights"4, та його перекладу, що представлений на сайті “Практика ЄСПЛ. Український аспект"5.

${ }^{3}$ Ця характеристика $є$ релевантною для художніх текстів та їхніх перекладів.

4 European Court of Human Rights [Електронний ресурс]. Режим доступу: https://www.echr.coe.int.

5 Практика ЄСПЛ. Український аспект [Електронний ресурс]. Режим доступу: https://www.echr.com.ua. 
Таблиця 3. Приклад картки метаданих юридичного тексту для англо-українського паралельного корпусу текстів

\begin{tabular}{|c|c|}
\hline Характеристика & Опис \\
\hline \multicolumn{2}{|r|}{ Текст оригіналу } \\
\hline Назва & Case of van de Kolk v. the Netherlands \\
\hline Мова оригіналу & англійська \\
\hline Автор & невідомий \\
\hline Стать автора ${ }^{6}$ & невідома \\
\hline Дата створення тексту & 2019 / 05 / 28 \\
\hline Дата публікації тексту & 2019 / 05 / 28 \\
\hline Місце публікації & Франція, м. Страсбург \\
\hline Видавництво / орган & http://hudoc.echr.coe.int/eng?i=001-193259 \\
\hline \multicolumn{2}{|r|}{ Текст перекладу } \\
\hline Назва перекладу & Ван де Колк проти Нідерландів \\
\hline Мова перекладу & українська \\
\hline Перекладач & $\begin{array}{l}\text { адвокат, кандидат юридичних наук, доцент, } \\
\text { заслужений юрист України Олександр Дроздов; } \\
\text { адвокат, кандидат юридичних наук, доцент Віктор } \\
\text { Янишен; адвокат, кандидат юридичних наук, директор } \\
\text { Адвокатського бюро <<Дроздова та партнери>> Олена } \\
\text { Дроздова; здобувач кафедри цивільного права № } 1 \\
\text { Національного юридичного університету ім. Я. } \\
\text { Мудрого Яна Токарь; Андрій Цибулько }\end{array}$ \\
\hline Стать перекладача & ч; ч; ж; ж; ч \\
\hline $\begin{array}{l}\text { Дата публікації } \\
\text { перекладу }\end{array}$ & 2019 / 06 / 11 \\
\hline Місце публікації & Україна, м. Київ \\
\hline Видавництво / орган & $\begin{array}{l}\text { https://www.echr.com.ua/translation/sprava-van-de-kolk- } \\
\text { proti-niderladniv-tekst-rishennya/ }\end{array}$ \\
\hline \multicolumn{2}{|c|}{ Спільні характеристики для текстів оригіналу й перекладу } \\
\hline Стиль & офіційно-діловий \\
\hline Підстиль & юридичний \\
\hline Вид правового акту & індивідуально-правовий \\
\hline Жанр тексту & рішення \\
\hline
\end{tabular}

Формування реєстру екстралінгвістичних міток закладає основи систематизації всіх корпусних текстів відповідно до релевантних для лінгвіста-дослідника та перекладача-практика показників. Ігнорування

${ }^{6}$ Ця характеристика є релевантною для художніх текстів та їхніх перекладів. 
перекладачем метаданих документу може привести до некоректного розуміння характеристик тексту й неправильного обрання еквівалентів перекладу, оскільки тексти, які навіть належать до одного підстилю (юридичні), але до різних жанрів можуть відрізнятися вокабуляром, граматичними конструкціями, що переважають, тощо.

\section{5. Висновки та перспективи}

Отже, будь-яка база даних потребує застосування чітких й обгрунтованих критеріїв для відбору даних, що наповнюють таку базу. На початковому етапі селекції текстів для англо-українського паралельного корпусу тексти мають бути схарактеризовані з точки зору мовної автентичності тексту оригіналу (англійська) та тексту перекладу (українська), жанрової приналежності через аналіз на відповідність всім критеріям жанровостильової класифікації та часу створення тексту.

Формулювання критеріїв відбору тексів неможливе без укладання класифікації таких текстів. Мовні твори, що складають текстовий масив юридичного корпусу, мають відповідати вимогам офіційно-ділового стилю юридичного підстилю, мати ознаки одного з трьох різновидів правового акту (нормативно-правовий, індивідуально-правовий, інтерпретаційноправовий) та відповідати певним жанровим характеристикам.

3 метою представлення в корпусі структурних, функціональних, дискурсивних та інших особливостей корпусних документів, швидкого опрацювання великих обсягів корпусної інформації, а також забезпечення оптимальної системи пошуку за певними ознаками кожного тексту виникає необхідність укладання структурованого та стандартизованого реєстру екстралінгвістичних характеристик та метатекстових даних корпусних текстів, що відображається в картці метаданих тексту.

Перспективним убачається подальша розробка розмітки англоукраїнського паралельного корпусу юридичних текстів, а саме, структурної та лінгвістичної.

\section{Бібліографія}

Анохіна, Т. О. (2018). Корпусний лакунікон англомовної та україномовної картин світу: монографія. Суми: Сумський державний університет. 
Бобкова, Т., Перебийніс, В., Сорокін, В. (2008). Частотні словники паралельних текстів. Людина. Комп'ютер. Комунікація: Збірник наукових праць. Львів: Вид. Національного університету «Львівська політехніка», с. 158-160.

Дарчук, Н.П., Лангенбах, М.О., Сорокін, В.М., Ходаківська, Я.В. (2017). Паралельний корпус текстів ПарКУМ. Науковий часопис Національного педагогічного університету імені М. П. Драгоманова. Серія 9: Сучасні тенденції розвитку мов: зб. наук. праць, 15, 28-35. Київ: Вид-во НПУ імені М.П. Драгоманова.

Дем'янчук, Ю. (2017). Паралельний корпус текстів: теоретико-методологічний та лексикографічний аналіз, принципи застосування. Записки з українського мовознавства, 24 (1), 285-293. https://doi.org/10.18524/2414-0627.2017.24.131389

Класифікатор галузей законодавства України, затверджений наказом Міністерства юстиції України від (02.06.04) № 43/5. [Електронний ресурс]. Режим доступу: https://minjust.gov.ua/m/str_8268

Kotsyba, N. (2016). Polsko-Ukraiński Korpus Równoległy PolUKR i jego następca PolUKR-2. In E. Gruszczyńska, A. Leńko-Szymańska (Eds.) Polskojęzyczne korpusy równoległe. Polish-language Parallel Corpora (pp. 133-142). Warszawa: Instytut Lingwistyki Stosowanej.

Лебєдєв, К. (2012). Створення Багатомовного корпусу паралельних текстів. Комп'ютерна лінгвістика: сучасне i майбутне. Матеріали Міжнародної науковопрактичної конференції, 1, 36-37.

Леміш, Н. (2018). Англо-український паралельний корпус текстів для студентів спеціальності “Переклад”. Актуальні проблеми романо-германської філологї та прикладної лінгвістики. наук. журн, 1(15), 207-210. Чернівці: ЧНУ.

Леміш, Н., Матвєєва, С. (2019). Морфологічна розмітка паралельного корпусу текстів для студентів спеціальності “Переклад”. Актуальні проблеми сучасної транслятологї, лінгвокраїнознавства та теорії міжкультурної комунікації: збірник матеріалів IV Всеукраїнської науково-практичної інтернет-конференції 3 міжнародною участю, 152-156. Вінниця: Редакційно-видавничий відділ ВТЕІ КНТЕУ.

Макович, Х.Я., Вербицька, Л.О., Капітан, Н.О. (2016). Словник термінів і понять з риторики. Львів: ЛДУБЖ.

McEnergy, T., Hardie, A. (2011). Corpus Linguistics: Method, Theory and Practice. Cambridge: University Press.

Рукосуєва, О.М. (2004). Класифікація законодавства України за галузями. [Електронний ресурс]. Режим доступу: https://minjust.gov.ua/m/str_2970

Селіванова, О.О. (2011). Лінгвістична енциклопедія. Полтава: Довкілля-К.

Сердюк, I.А. (2010). Нормативно-правовий акт у співвідношенні 3 актом застосування та актом тлумачення норм права. Вісник Луганського державного університету внутрішніх справ імені Е.О. Дідоренка, 3, 152-159. 
Siruk, O., Derzhanski, I. (2013). Linguistic Corpora as International Cultural Heritage: The Corpus of Bulgarian and Ukrainian Parallel Texts. Digital Presentation and Preservation of Cultural and Scientific Heritage, 3, 91-98.

Січінава, Д.В., Тищенко-Монастирська О.О., Шведова М.О. (2011). Паралельні українсько-російський та російсько-український корпуси. Лексикографічний бюлетень, 20, 35-38.

\section{References}

Anokhina, T. O. (2018). Korpusnyy lakunikon anhlomovnoyi ta ukrayinomovnoyi kartyn svitu: monohrafiya. Sumy: Sums'kyy derzhavnyy universytet.

Bobkova, T., Perebyynis, V., Sorokin, V. (2008). Chastotni slovnyky paralel'nykh tekstiv. Lyudyna. Komp"yuter. Komunikatsiya: Zbirnyk naukovykh prats'. L'viv: Vyd. Natsional'noho universytetu «L'vivs'ka politekhnika», c. 158-160.

Dem"yanchuk, YU. (2017). Paralel'nyy korpus tekstiv: teoretyko-metodolohichnyy ta leksykohrafichnyy analiz, pryntsypy zastosuvannya. Zapysky z ukrayins'koho movoznavstva, $24 \quad$ (1), 285-293. https://doi.org/10.18524/24140627.2017.24.131389

Darchuk, N.P., Lanhenbakh, M.O., Sorokin, V.M., Khodakivs'ka, YA.V. (2017). Paralel'nyy korpus tekstiv ParKUM. Naukovyy chasopys Natsional noho pedahohichnoho universytetu imeni M. P. Drahomanova. Seriya 9: Suchasni tendentsiyi rozvytku mov: zb. nauk. prats', 15, 28-35. Kyyiv: Vyd-vo NPU imeni M.P. Drahomanova.

Klasyfikator haluzey zakonodavstva Ukrayiny, zatverdzhenyy nakazom Ministerstva yustytsiyi Ukrayiny vid (02.06.04) 43/5. [Elektronnyy resurs]. Rezhym dostupu: https://minjust.gov.ua/m/str_8268

Kotsyba, N. (2016). Polsko-Ukraiński Korpus Równoległy PolUKR i jego następca PolUKR-2. In E. Gruszczyńska, A. Leńko-Szymańska (Eds.) Polskojęzyczne korpusy równoległe. Polish-language Parallel Corpora (pp. 133-142). Warszawa: Instytut Lingwistyki Stosowanej.

Lebyedyev, K. (2012). Stvorennya Bahatomovnoho korpusu paralel'nykh tekstiv. Komp"yuterna linhvistyka: suchasne $i$ maybutnye. Materialy Mizhnarodnoyi naukovopraktychnoyi konferentsiyi, 1, 36-37.

Lemish, N. (2018). Anhlo-ukrayins'kyy paralel'nyy korpus tekstiv dlya studentiv spetsial'nosti "Pereklad". Aktual'ni problemy romano-hermans' koyi filolohiyi ta prykladnoyi linhvistyky: nauk. zhurn, 1(15), 207-210. Chernivtsi: CHNU.

Lemish, N., Matvyeyeva, S. (2019). Morfolohichna rozmitka paralel'noho korpusu tekstiv dlya studentiv spetsial'nosti "Pereklad". Aktual ni problemy suchasnoyi translyatolohiyi, linhvokrayinoznavstva ta teoriyi mizhkulturnoyi komunikatsiyi: zbirnyk materialiv IV Vseukrayins' koyi naukovo-praktychnoyi internet-konferentsiyi $z$ mizhnarodnoyu uchastyu, 152-156. Vinnytsya: Redaktsiyno-vydavnychyy viddil VTEI KNTEU. 
Makovych, KH.YA., Verbyts'ka, L.O., Kapitan, N.O. (2016). Slovnyk terminiv i ponyat' z rytoryky. L'viv: LDUBZH.

McEnergy, T. \& Hardie, A. (2011). Corpus Linguistics: Method, Theory and Practice. Cambridge: University Press.

Rukosuyeva, O.M. (2004). Klasyfikatsiya zakonodavstva Ukrayiny za haluzyamy. [Elektronnyy resurs]. Rezhym dostupu: https://minjust.gov.ua/m/str_2970

Selivanova, O.O. (2011). Linhvistychna entsyklopediya. Poltava: Dovkillya-K.

Serdyuk, I.A. (2010). Normatyvno-pravovyy akt u spivvidnoshenni z aktom zastosuvannya ta aktom tlumachennya norm prava. Visnyk Luhans'koho derzhavnoho universytetu vnutrishnikh sprav imeni E.O. Didorenka, 3, 152159.

Siruk, O., Derzhanski, I. (2013). Linguistic Corpora as International Cultural Heritage: The Corpus of Bulgarian and Ukrainian Parallel Texts. Digital Presentation and Preservation of Cultural and Scientific Heritage, 3, 91-98.

Sichinava, D.V., Tyshchenko-Monastyrs'ka O.O., Shvedova M.O. (2011). Paralel'ni ukrayins'ko-rosiys'kyy ta rosiys'ko-ukrayins'kyy korpusy. Leksykohrafichnyy byuleten', 20, 35-38. 
